\title{
FIRST ECOLOGICAL DATA OF FLYING FOXES OF THE GENUS Pteropus (Chiroptera: Pteropodidae) IN VIETNAM
}

\author{
Vu Dinh Thong ${ }^{1 *}$, Nguyen Thanh Tung ${ }^{2}$, Nguyen Tran Thanh Tinh ${ }^{2}$ \\ ${ }^{1}$ Institute of Ecology and Biological Resources, VAST, *vietnambat@gmail.com \\ ${ }^{2}$ Can Tho University
}

\begin{abstract}
Flying fox is the common name of all fruit bat species of the genus Pteropus. Prior to this study, Vietnamese flying foxes were poorly studied and their ecology was almost unknown. To fill this gap, we conducted monthly surveys between January and September 2014 in Soc Trang province with emphasis on variations of colony size, diet and roosting behavior of flying foxes. The surveys included observational counting, field identification of flying foxes and identification of food samples and their roosting trees. Results from the surveys indicated that the colony comprises two species, the larger of which is Pteropus lylei and the smaller one is provisionally identified as Pteropus cf. hypomelanus. Although there are nearly one thousand trees in the study site, flying foxes roost under the canopies of very few. The colony size varies weekly, monthly and seasonally with a total number of individuals ranging between 453 in April and 1,753 in February. This paper also provides a risk assessment and recommendations for urgent conservation of these threatened mammals.
\end{abstract}

Keywords: Pteropus, conservation, ecology, mammalia, monitoring.

\section{INTRODUCTION}

Flying foxes (Pteropus spp.) comprises 65 species worldwide (Simons 2005) [9]. Of which, three species, viz. $P$. hypomelanus, $P$. lylei and $P$. vampyrus, are known from Vietnam $[5,9,12]$. They were widely recorded in the South Central and Mekong Delta regions of the country [12]. Unfortunately, they were critically threatened by habitat loss and illegal hunting $[10,12]$. Therefore, these species are survived within only five narrow sites of the Mekong Delta region: Can Gio Biosphere Reserve of Ho Chi Minh city, Con Dao National Park of Ba Ria-Vung Tau province, Hon Khoai island of $\mathrm{Ca} \mathrm{Mau}$ province, $\mathrm{Phu}$ Quoc National Park of Kien Giang province and Soc Trang city of Soc Trang province [5, 12].

Historically, the first published records of flying foxes from Vietnam were included in Peters (1869) [7], which also appears as the first published literature regarding the bat fauna of the country $[3,13]$. Subsequently, records of these bat species were included in several publications $[1,3,10,12]$. Peters (1869) classified materials from Condor Island, an island of the Con Dao Archipelago National
Park in southern Vietnam, as a new species, namely Preropus condorensis. However, Corbet \& Hill (1992) [2] listed the "Preropus condorensis" as a synonym of Pteropus hypomelanus whilst Simmons (2005) [9] treated it as a subspecies of Pteropus hypomelanus. Kruskop (2013) [5] examined the type specimen of "Preropus condorensis" and identified two recently collected specimens from Condor Island as Pteropus hypomelanus. Nevertheless, the taxonomic status of "Preropus condorensis/hypomelanus" is still unclear. In fact, all previous publications including Corbet \& Hill (1992) [2], Simmons (2005) [9] and Kruskop (2013) [5] did not provide any taxonomic assessment of the species. Therefore, we provisionally treat materials of small flying foxes from Vietnam as Pteropus cf. hypomelanus and hope to resolve its taxonomy in the future. Over the past ten years, numbers of flying fox colonies and individuals of each colony have been critically decreased [12, 13]. In Soc Trang province, which is home to the most important colony of flying foxes in Vietnam, the People's Committee has issued and implemented a provincial law for protection of flying foxes 
throughout its territory. Unfortunately, the local law is likely to be ineffective. The local authorities have tried their best with considerable efforts but they lack knowledge of the issue and how to implement the policy. Logically, without an appropriate ecological background, strategies for conservation of bats and general biodiversity are likely to be impractical.

To fill the current gap as well as strengthen local laws for effective conservation of Vietnamese flying foxes, with supports from the Food and Agriculture Organization (FAO) of the United Nations, the People's Committee of Soc Trang province through the Department of Science and Technology, we conducted an ecological study of the flying fox colony in Soc Trang province. This paper provides initial results from our study with emphases on their roosting behavior, common food compositions and colony size variations.

\section{MATERIALS AND METHODS}

Field surveys were conducted monthly at Soc Trang city of Soc Trang province, between January and September in 2014. Flying foxes were counted precisely at their roosts through observation in the daytime by the second and third authors. Additionally, four stations around their roosts were also designated for counting in the evening and early morning. Counters, binoculars, cameras and video cameras were employed during all observational processes for maximum accuracy of the results. Daily number of flying foxes is the average of counting numbers from all counters.

All trees within the studied site were identified by a senior botanist of IEBR, Dr. Ha Van Tue, then numbered and mapped to assess the roosting behavior of the flying foxes colony (fig. 1). Food composition was identified based on remaining fruits under the roosts and seeds in randomly selected fecal samples. Results from direct observation during moonlight nights also supported and provided additional data on the food composition. Dead individuals (fig. 2) of flying foxes under the roosts were collected for an examination of their taxonomy at IEBR by the first author. Reproductive status of flying foxes was assessed following Racey (2009) [8].

\section{RESULTS AND DISCUSSION}

\section{Current status and variations of colony size}

The studied colony of flying foxes in Soc Trang varies between 453 and 1,753 individuals. The obtained results indicated that the colony varied weekly and monthly (tables $1,2)$. The highest and lowest numbers of flying foxes were recorded in February and April, respectively. The monthly variation coresponds with the food sources of flying foxes. Between February and May is the beginning of annual fruit season in Soc Trang and surrounding province. Therefore, numbers of flying foxes at the study site are much higher than those in remaining months of the year.

The colony was also strongly threatened by human activities. In April, when the Chol Chnam Thmay traditional festival of local people was organized at the study site, flying foxes were disturbed by noise, smoke and tourists' activities. Very few flying foxes remained at the study site during the festival (table 1). It is noticeable that the festival occurs annually, in the breeding season of flying foxes and numbers of tourists visiting the site during the festival have continuously increased since 2004. The flying fox colony also exhibited a weekly variation. Numbers of flying foxes during the week days are much higher than those at the weekend (table 2 ). The variation corresponds to daily variations of tourist numbers.

\section{Roosting behavior of flying foxes}

Vegetation of the study site is quite diverse in terms of species and canopy layers. It is noticeable that flying foxes only roosted in very few trees, which are higher than 15 meters, among nearly 2,000 trees within the study site. They daily leave their roosts around 18:00 $\mathrm{h}$ and return between 03:00 $\mathrm{h}$ and 05:00 $\mathrm{h}$.

\section{Food composition}

Two different species of flying foxes were observed at the study site during the field surveys. Six individuals of the larger species were randomly captured by the first author and 
others in 2013 and identified as Pteropus lylei. The smaller form is quite similar to Pteropus cf. hypomelanus. Within the aims of this study, we investigated the food composition of Pteropus lylei. Four plant species: tropical almond,

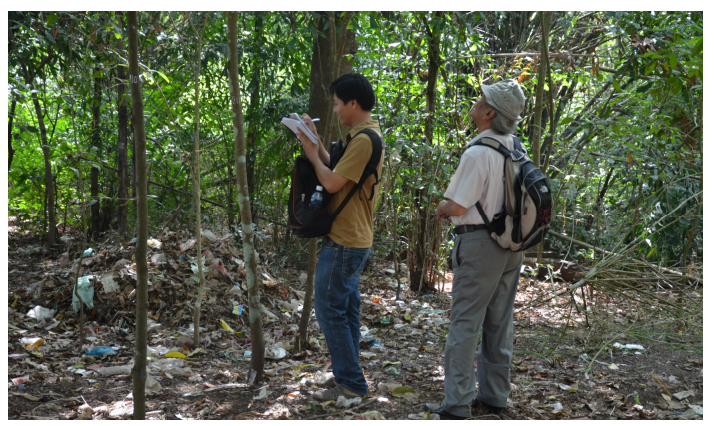

Figure 1. Mapping the trees of the study site

Table 1. Monthly variations and breeding indicator of the flying fox colony Soc Trang province during 2014

\begin{tabular}{ccc}
\hline Date of surveys & Mean \pm SD & Pub $^{*}$ \\
\hline 20 th Jan. & $1169 \pm 27$ & 0 \\
$27^{\text {th }}$ Feb. & $1753 \pm 39$ & 0 \\
$29^{\text {th }}$ Mar. & $633 \pm 7$ & 0 \\
$15^{\text {th }}$ Apr. & $453 \pm 4$ & 0 \\
$29^{\text {th }}$ Apr. & $1278 \pm 20$ & $56 \pm 2$ \\
$29^{\text {th }}$ May & $1627 \pm 15$ & $173 \pm 4$ \\
$15^{\text {th }}$ June & $1080 \pm 19$ & $109 \pm 3$ \\
$28^{\text {th }}$ Jun. & $998 \pm 21$ & $125 \pm 3$ \\
$16^{\text {th }}$ Jul. & $887 \pm 11$ & $109 \pm 2$ \\
$26^{\text {th }}$ Jul. & $753 \pm 6$ & $95 \pm 1$ \\
$16^{\text {th }}$ Aug. & $976 \pm 18$ & $102 \pm 2$ \\
$23^{\text {rd }}$ Aug. & $1111 \pm 21$ & $114 \pm 3$ \\
$12^{\text {th }}$ Sep. & $1485 \pm 28$ & $100 \pm 2$ \\
\hline
\end{tabular}

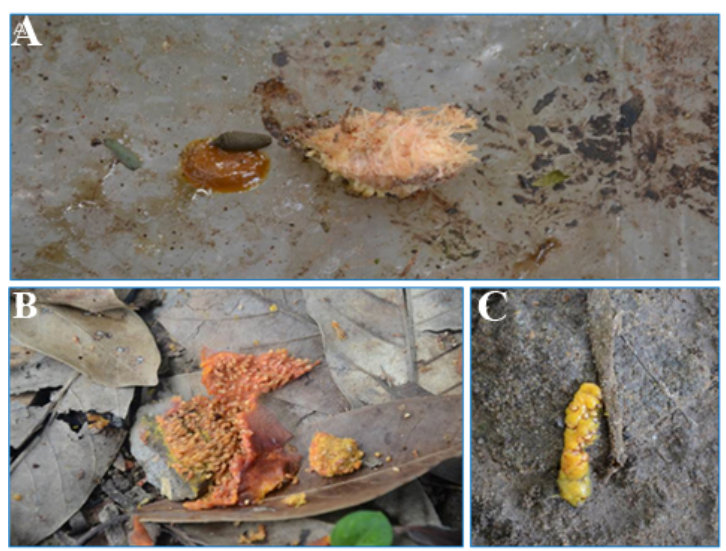

Terminalia catappa; brown-woolly fig, Ficus drupacea; Calabur tree, Muntingia calabura and sacred fig, Ficus religiosa provide food for Pteropus lylei within and sounding the study site (fig. 3).

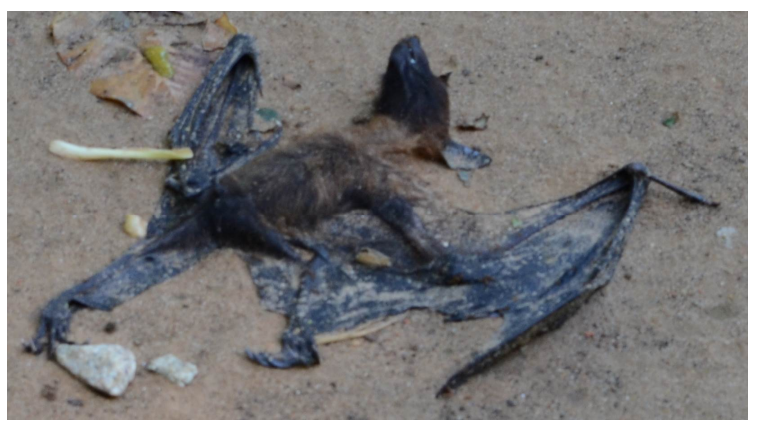

Figure 2. A dead flying fox at the study site

Table 2. Weekly variation of the flying fox colony between 03rd and 14th September 2014

\begin{tabular}{ccc}
\hline & Date & $\begin{array}{c}\text { Numbers of } \\
\text { flying foxes }\end{array}$ \\
\hline $3^{\text {rd }}$ & Wed & $1314 \pm 25$ \\
$4^{\text {th }}$ & Thu & $1278 \pm 22$ \\
$5^{\text {th }}$ & Fri & $1089 \pm 16$ \\
$6^{\text {th }}$ & Sat & $1023 \pm 17$ \\
$8^{\text {th }}$ & Mon & $1440 \pm 26$ \\
$9^{\text {th }}$ & Tue & $1469 \pm 31$ \\
$10^{\text {th }}$ & Wed & $1470 \pm 28$ \\
$11^{\text {th }}$ & Thu & $1537 \pm 26$ \\
$12^{\text {th }}$ & Fri & $1485 \pm 28$ \\
$13^{\text {rd }}$ & Sat & $1320 \pm 30$ \\
$14^{\text {th }}$ & Sun & $1217 \pm 18$ \\
\hline
\end{tabular}

*Observed pups were carried by female flying foxes.

Figure 3. Food remains of Pteropus lylei at the roosting site in Soc Trang province from two plant species: Terminalia catappa (A) and Ficus drupacea $(\mathrm{B}, \mathrm{C})$.

To minimize the disturbance to flying foxes in Soc Trang province, the traditional festival should be organized outside the study site or at least one kilometer from the flying foxs' roosting site. Results from a previous study indicated that flying foxes in Soc Trang province forage daily up to 50 kilometers from their roosts. Information from the present study 
is insufficient to confirm a hypothesis regarding the selection of roosts by flying foxes. It is very likely that flying foxes prefer old trees to the younger ones. In fact, all trees in which the flying fox colony roosts are older than 20 years. Further studies on the ecology of the flying fox colony are clearly required to provide further information for timely and effective conservation strategies.

Published information about the diet of Pteropus lylei is sparse. Lanlua et al. (2007) [6] indicated that Pteropus lylei "consumes only ripe fruit, which contains low protein and sodium". Dietary samples collected during the present study also exhibit the remains of ripe fruits.

\section{CONCLUSION}

Flying foxes currently remain within the Mekong Delta region of Vietnam with only two permanent roosts: the garden of the Chua Doi, Soc Trang city, Soc Trang province and Can Gio Biosphere, Ho Chi Minh city.

Chua Doi pagoda in Soc Trang province is currently a home to two different species of flying foxes: the larger is Pteropus lylei whilst the smaller likely belongs to Pteropus cf. hypomelanus.

The colony of Pteropus lylei at Chua Doi pagoda exhibits weekly, monthly and seasonally variations ranging between 453 and 1,753 individuals.

The flying foxes roost only beneath the canopy of trees older than 20 years. They leave the roost daily around 18:00 $\mathrm{h}$ and return between 03:00 $\mathrm{h}$ and 05:00 h.

Pteropus lylei in Vietnam feeds on at least four plant species: Terminalia catappa, Ficus drupacea, Muntingia calabura and Ficus religiosa.

Acknowledgements: This research is funded by the Vietnam National Foundation for Science and Technology Development (NAFOSTED) under grant number 106.11-2012.02; the Food and Agriculture Organisation of the United Nations in Vietnam (FAOVN); the Soc Trang People's Committee through the Department of
Science and Technology of Soc Trang province (DSTS); The Rufford Foundation of England under the grant "RSG I.D: 15184-1". The author is very grateful to Dr. Scott Newman of FAOVN; Dr Paul J.J. Bates of the Harrison Institute, England; Prof. Paul Racey of the University of Exeter, England; Dr. Neil Furey of the Fauna and Flora International (Cambodia); Dr. Tigga Kingston of Texas Tech University, USA; Dr. Duong Van Ni of Can Tho University; Dr. Vu Thi Hieu Dong (Director of DSTS); Dr. Tran Minh Hoi and to our colleagues at the Institute of Ecology and Biological Resources, Institute of Tropical Biology, VAST, and other institutions for their help and support.

\section{REFERENCES}

1. Cao Van Sung, Eger J., Ngo Van Tri, 2000. Preliminary report on bat survey in southern Vietnam. Tap chi Sinh hoc, 22(15)CD: 136144 (Vietnamese with English summary).

2. Corbet G. B., Hill J. E., 1992. The Mammals of the Indomalayan Region. Oxford University Press: 488pp.

3. Hendrichsen D. K., Bates P. J. J., Hayes B. D., Walson J. L., 2001. Recent records of bats (Mammalia: Chiroptera) from Vietnam with six species new to the country. Myotis, 39: 35-199.

4. Dang Huy Huynh (ed.), Dao Van Tien, Cao Van Sung, Pham Trong Anh, Hoang Minh Khien, 1994. Checklist of mammals in Vietnam. Publishing House "Science and Technics", Hanoi, 168 pp [in Vietnamese].

5. Kruskop S. V., 2013. Bats of Vietnam: Checklist and an identification manual. Moscow, Russia, 299 pp.

6. Lanlua P., Sricharoenvej S., Niyomchan A., Chico D. E., 2007. Unique cellular structures in the parotid gland of an Old world fruit bat, Pteropus lylei (Lyle's flying fox). Italian Journal of Anatomy and Embryology, 112(3): 179-190.

7. Peters W., 1869. Bemerkungen ueber neue oder weniger bekannte Flederthiere, besonders des Pariser Museums. 
Buchdruckerei der Koenigl. Academie der Wissenschften, Berlin: 391-406.

8. Racey P. A., 2009. Reproductive assessment in bats. In: Kunz T. H., Parsons S. (eds.) Ecological and Behavioral Methods for the Study of Bats, 2nd edition, Johns Hopkins University Press, Baltimore, pp. 249-264.

9. Simmons N. B., 2005. Order Chiroptera. In: Wilson DE and Reeder DM (eds.) Mammal species of the world: A taxonomic and geographic reference. The Johns Hopkins University Press, Baltimore, 3rd edition, pp. 312-529.

10. Nguyễn Trường Sơn, Vũ Đình Thống, Phạm Đức Tiến, Nguyễn Vũ Khôi, 2009. Hiện trạng các loài dơi thuộc giống Pteropus ở Việt Nam. Tạp chí Sinh học, 31(3): 52-57.

11. Van Peneen P. F. D., Ryan P. E., Light R. H., 1977. Preliminary identification manual for mammals of South Vietnam. United States National Museum Washington D.C.: 30-48.

12. Vũ Đình Thống, 2004. Dẫn liệu mới về các loài dơi ngựa (Pteropus spp.) và hiện trạng của chúng ở Việt Nam. Tạp chí Sinh học, 26(3): 10-17.

13. $\mathrm{Vu}$ Dinh Thong, 2011. Systematics and echolocation of rhinolophoid bats (Mammalia: Chiroptera) in Vietnam. PhD Thesis, University of Tuebingen, Tuebingen, Germany, $258 \mathrm{pp}$.

\title{
DÃ̃ LIỆ ĐẦU TIÊN VỀ SINH THÁI HỌC CỦA DƠI NGỤAA GIỐNG Pteropus (Chiroptera: Pteropodidae) Ở VIỆT NAM
}

\author{
Vũ Đình Thống ${ }^{1}$, Nguyễn Thanh Tùng ${ }^{2}$, Nguyễn Trần Thanh Tính ${ }^{2}$ \\ ${ }^{1}$ Viện Sinh thái và Tài nguyên sinh vật, Viện Hàn lâm KH \& CN Việt Nam \\ ${ }^{2}$ Trường Đại học Cần Thơ
}

\section{TÓM TÁT}

Dơi ngựa là tên phổ thông của tất cả những loài dơi ăn quả thuộc giống Pteropus. Trước khi nghiên cứu này được thực hiện, hầu như chưa có dẫn liệu nào về sinh thái của những loài dơi ngựa ở Việt Nam cũng như các nước trong khu vực Đông Nam Á. Nhằm góp phần khắc phục sự thiếu dẫn liệu đó, chúng tôi đã thực hiện những đợt điều tra thực địa theo định kỳ mỗi tháng một lần (từ tháng 1 đến tháng 9 năm 2014) ở tỉnh Sóc Trăng; tập trung nghiên cứu sự thay đổi số lượng cá thể trong đàn dơi ngựa, thành phần thức ăn và tập tính đậu của chúng. Các đợt điều tra thực địa bao gồm: đếm số lượng cá thể qua quan sát ban ngày, thu và định loại những mẫu thức ăn của dơi, định loại những cá thể dơi quan sát được và những cây có dơi đậu. Đàn dơi ở khu vực nghiên cứu gồm hai nhóm cá thể được định danh là Pteropus lylei và Pteropus cf. hypomelanus. Trong số gần hai nghìn cây ở khu vực nghiên cứu, dơi ngựa chỉ đậu ở một số ít cây trên 20 năm tuổi. Số lượng cá thể trong đàn dơi thay đổi theo chu kỳ ngày trong tuần, thay đổi qua từng tháng và mùa trong năm với số lượng cá thể trong khoảng từ 453 đến 1.753. Bài báo này cũng cung cấp dẫn liệu đầu tiên về thức ăn của dơi ngựa ở Việt Nam cũng như ở khu vực Đông Nam Á, mối đe dọa đối với đàn dơi ngựa và một số đề xuất nhằm bảo tồn chúng kịp thời trong thời gian tới.

Tư khóa: Mammalia, Pteropus, bảo tồn, sinh thái học, phân loại học.

Ngày nhận bài: 7-7-2015 